\title{
Entrevista: \\ Paulo Vannuchi
}

\author{
Entrevistadores: \\ Bianca Tavolari \\ Igor Machado \\ Júlia Chiacchio \\ Renan Quinalha \\ Úrsula Passos
}

Paulo Vannuchi é graduado em jornalismo pela ECA-USP e mestre em ciência política pela FFLGH-USP. Foi militante de oposição ao regime militar, tendo sido inclusive preso político. Participou ainda do projeto Brasil: nunca mais, um levantamento dos crimes cometidos pelos órgãos de repressão política, feito sob sigilo durante a ditadura militar - que hoje está em sua 38 . $^{a}$ edição. Membro do Partido dos Trabalhadores (PT) desde a década de I980, na segunda gestão do governo Lula assumiu a chefia da Secretaria de Direitos Humanos da Presidência da República, recentemente alçada ao status de Ministério.

Tardiamente publicada, esta entrevista com o então ministro Paulo Vannuchi foi realizada em 3I de maio de 20IO. No entanto, se a entrevista se encontra datada, não podemos deixar de notar sua relevância para a reflexão sobre a história e a situação atual de nosso país. O ano de 2010 foi especialmente oportuno para o debate sobre os direitos humanos, sobretudo quanto aos primeiros passos consolidados pela sociedade civil em direção à apuração das violações promovidas pela ditadura militar. Portanto, nas próximas páginas o leitor tem acesso ao testemunho privilegiado de eventos históricos decisivos para a construção da democracia brasileira. 
Humanidades em Diálogo - Desde o seu lançamento, o terceiro Programa Nacional de Direitos Humanos enfrenta, por um lado, as críticas da imprensa e de intelectuais sobre o extenso catálogo de direitos humanos que apresenta e, por outro lado, a ignorância de grande parte da população sobre quais direitos são considerados "direitos humanos". O Relatório de Desenvolvimento Humano da ONU, cuja edição começou em I990, estabeleceu que "direitos humanos" abarcam direitos sociais, econômicos e culturais, além dos direitos civis e políticos. Em artigo publicado em I99I na revista Novos Estudos, intitulado "Direitos humanos ou privilégio de bandido?", a antropóloga Teresa Caldeira expôs uma pesquisa que mostra que é comum, principalmente entre os setores mais desfavorecidos, a ideia de que os direitos humanos seriam apenas os direitos civis, além de um forte preconceito social que associa direitos humanos a regalias concedidas a infratores. Paralelamente, editoriais têm publicado a opinião de que os direitos humanos devem abranger tão somente direitos civis e liberdades públicas. Diante desse cenário, em que se nota um imaginário social contra os direitos humanos, qual é o papel do $\mathrm{PNDH}-3$ e como ele pode ser efetivado?

Paulo Vannuchi - A reação ao PNDH-3 tem algumas características conjunturais. Seria muito ruim para o país e para os direitos humanos se o $\mathrm{PNDH}-3$ não divergisse do pensamento que existe. Em favor da minha tese, eu lembro que o primeiro PNDH, de I996, e o segundo, de 2002, que têm muitas semelhanças com o terceiro, não tiveram reação comparável. Então, evidentemente, a reação tem uma particularidade conjuntural: seja o cenário eleitoral, seja o fato de ter desencadeado uma controvérsia dentro do governo - que classicamente é um prato cheio para a oposição -, seja pelo momento especial - que eu considero o clímax do ruim - do alinhamento partidário-político da imprensa. A Judith Brito, presidente da Associação Nacional de Jornais, confessou claramente em uma reunião da associação que os partidos estão muito fracos, que os jornais é que estão fazendo o papel deles. Eu espero que o pensamento sobre direitos humanos no Brasil não seja tão fóbico, "coisa do demônio", como tem aparecido. A Kátia Abreu ${ }^{1}$ só consegue falar do PNDH-3 como "excrescência". Evidentemente é um grave surto de reacionarismo que, de mais a mais, como cientista político, eu penso que possa se tratar de um grande blefe: uma reação tão exagerada,

I Kátia Abreu. Pecuarista e presidente da Confederação da Agricultura e Pecuária do Brasil, filiada ao DEM (antigo PFL), na primeira metade desta década foi eleita deputada federal por Tocantins, sendo líder da Bancada Ruralista da Câmara Federal dos Deputados. Atualmente é senadora pelo mesmo estado. 
tão distorcida, pode ser essencialmente falsa, falando em nome de ninguém. O velho conceito distorcido de direitos humanos, "coisa de preso", "coisa de bandido", não é um senso comum autogestado: ele foi introjetado no final do regime militar. Eu me lembro ainda do tom de Paulo Maluf ${ }^{2}$ e Afanásio Jazadji ${ }^{3}$ dizendo: "direitos humanos é coisa de bandido". Isso foi dito no momento em que o regime estava sendo derrotado, mas ainda com força suficiente para liderar e conduzir todo o processo de abertura - ao contrário, por exemplo, da Argentina, onde o fim do regime foi um desmoronamento. Nós fizemos uma pesquisa de percepção dos direitos humanos, com o Gustavo Venturi, que foi dirigente do Datafolha por muito tempo, e a pergunta "Direitos humanos é coisa de bandido?" teve 9\% de concordância. O que acontece é que as pessoas que têm fortemente essa visão distorcida atuam nas rádios, nas correspondências de jornais, e por isso ela aparece constantemente. Precisaríamos fazer uma ampla pesquisa para medir a adesão a essa ideia. Bobbio diz que os direitos humanos não nascem todos de uma vez nem de uma vez por todas. Há uma primeira geração, a dos direitos civis e políticos, e uma segunda geração, a dos direitos econômicos, sociais e culturais. Grosso modo, as gerações refletem os velhos temas dos direitos de liberdade e de igualdade, concepções que foram ora do pensamento liberal, ora do pensamento democrático e/ou socialista. Houve uma oposição - que não é boa - entre estes dois pensamentos: para um bom pensamento democrático e socialista o importante seria a igualdade e não a liberdade; de outro lado, haveria o cinismo da liberdade, por exemplo, uma sociedade supostamente livre onde há trabalho escravo. A ONU foi fundada em I945; a Declaração Universal dos Direitos Humanos é de I948; em I966, dezoito anos depois da Declaração, foi preciso votar na Assembleia Geral da ONU dois Tratados de Direitos Humanos diferentes, que deveriam, na verdade, ser um único Tratado de Direitos Humanos, o instrumento vinculativo da Declaração. Uma declaração é genérica e um tratado

2 Paulo Maluf. Engenheiro e empresário, durante o período militar foi nomeado prefeito de São Paulo, secretário estadual de transportes de São Paulo e, pela ARENA, eleito indiretamente governador do estado; em I984 e I989, pelo PDS (antigamente ARENA), foi candidato à presidência da república; por voto direto, pelo PDS, foi eleito deputado federal por São Paulo e prefeito de São Paulo; atualmente, filiado ao PP (antigo PDS), exerce seu segundo mandato como deputado federal pelo mesmo estado.

3 Afanásio Jazadji. Advogado e comunicador, foi cinco vezes consecutivas eleito deputado estadual de São Paulo, pelo PDS, PST e PFL, sendo atualmente filiado ao PMDB, embora não exerça cargo político; é recordista de audiência pela sua atuação na imprensa sensacionalista e, como membro da Comissão Permanente de Segurança Pública da Assembleia Legislativa, destacou-se pela defesa da pena de morte e da revogação da lei contra discriminação por orientação sexual. 
é um instrumento a que os países aderem, cumprem relatórios quinquenais etc ${ }^{4}$. Foram votados dois Tratados por causa dos desacordos sobre direitos de igualdade e de liberdade entre as potências. Numa matéria com a manchete "Muito além dos direitos humanos", publicada [no dia 08 de janeiro de 20IO] em primeira página n' $O$ Globo, o jornalista José Casado afirma: "direitos humanos são direitos civis e políticos". Ora, na sua ignorância temática, os jornalistas não buscam se informar e fazem uma distorção. E, da nossa parte, o Programa não foi pensado para fazer um escândalo, mas como um instrumento cauteloso com a conjuntura e com a relação de forças. Evidentemente, se eu pudesse imaginar tudo que aconteceu, eu teria tido três vezes mais cautela no texto. Mas é a Conferência ${ }^{5}$ que aprova o esqueleto do Programa. E toda a negociação com a sociedade civil, com os articuladores da conferência, foi difícil, porque as pessoas começaram a tencionar que nós estávamos recuando. Era "Comissão da Verdade e da Justiça": nós tornamos somente "da Verdade". Aliás, a Conferência não aprova o Programa - todos sabiam disso. O Programa é um decreto presidencial que envolve situação constitucional, orçamentária, legal, restrições do governo e dos vários partidos da base aliada etc. Nesse sentido, um bom Programa de Direitos Humanos tinha de ser como foi o PNDH-3, ou seja, articulando em seis eixos a compreensão atualizada de direitos de primeira e de segunda gerações. Não existe, sem nenhuma controvérsia, a concepção de que direitos econômicos, sociais e culturais não sejam direitos humanos. O que existe é este senso comum, um pensamento reacionário e, pior do que isso, uma lamentável incompetência, um desconhecimento por parte de setores que precisariam saber do que estão falando. Nesse sentido, o lançamento do PNDH-3 também teve um lado muito bom, porque suscitou um debate inédito, em termos de número de páginas de jornal, discussões nas universidades etc. Além disso, nós temos duas reações ao PNDH-3. Uma delas, que provavelmente $95 \%$ dos brasileiros acreditam ser a única, é a que escorraçou o Programa. A força que a mídia tem hoje é tamanha que parece que há quatro poderes em vez de três. O Jânio de Freitas - que eu respeito muito - fala do

4 Uma declaração internacional é um ato unilateral do Estado ou de um órgão internacional por meio do qual se faz uma enumeração de obrigações ou de direitos. A mera declaração não gera, para o(s) Estado(s), dever algum. É apenas uma manifestação que visa a positivar, a título de respeito, determinada matéria. Já o tratado internacional é um acordo bilateral entre sujeitos de Direito Internacional, pelo qual surgem direitos e obrigações, cujo descumprimento, por sua vez, dá ensejo a sanções internacionais.

5 A terceira versão do PNDH, instituída por decreto presidencial de 2I de dezembro de 2009, é fruto do debate promovido entre representantes de entidades nacionais e militantes de direitos humanos e membros do governo federal pela $\mathrm{II}^{\mathrm{a}}$ Conferência de Direitos Humanos, realizada entre os dias $\mathrm{I} 5$ e I 8 de dezembro de 2008 em Brasília, com o intuito de revisar e atualizar o Programa Nacional de Direitos Humanos de 1996 que já havia sido ampliado em 2002. 
PNDH-3 como "a mais tresloucada peça já produzida, não apenas no governo Lula, mas em todo o período da redemocratização". Eu mandei um recado por um assessor meu que trabalhou com ele: "essa frase só pode ser escrita por alguém que não leu o documento"; e ele reconheceu: "não li". Então, se até pessoas da envergadura do José Casado ou do Jânio de Freitas - que dizem ter inspirado o Paulo Martins de Terra em transe do Glauber Rocha - escrevem bobagens como essa, há um grande problema que a democracia brasileira precisa decifrar - sem que isso leve à censura. A primeira reação a toda discussão que nós propomos é a acusação de que nós queremos impor censura, de que o governo Lula é chavistabolivariano. Ora, temos a prova cabal do contrário: o presidente só não tem o terceiro mandato na mão - e a eleição já teria acabado - porque não quer; e não quis porque avalia que a democracia brasileira é jovem demais para passar pelo trauma de ter o processo eleitoral alterado no meio de um mandato. O PNDH-3 teve muito apoio, só que o apoio que não aparece na mídia se desfaz. $\mathrm{O}$ ataque da $\mathrm{CNA}^{6}$ foi muito divulgado, mas a CONTAG ${ }^{7}$ publicou na capa do seu jornal todo apoio ao PNDH $-3^{8}$. Ora, a CNA não é mais importante que a CONTAG, nem em número de gente nem em importância no PIB agrícola. Nenhum grão de soja é produzido sem o trabalhador. A CNA teoricamente representa - e representa mal - os empresários, enquanto a CONTAG representa os trabalhadores rurais. Outras entidades que apoiaram o Programa foram a OAB [Ordem dos Advogados do Brasil], o Ministério Público pelo seu Conselho Nacional, a Defensoria Pública do Rio de Janeiro, o Conselho Federal de Psicologia, a Federação Nacional dos Médicos, CREAs [Conselhos Regionais de Engenharia, Arquitetura e Agronomia] de vários lugares, a Federação Nacional dos Jornalistas, a Comissão de Direitos Humanos da Câmara Federal dos Deputados, partidos como o PT, o PCdoB, o PDT e o PSB em notas formais. E, ainda assim, o PNDH-3 é tratado como algo que foi execrado.

Humanidades em Diálogo - Segundo Renato Janine Ribeiro, dois eventos cruciais da história brasileira são marcados por total ausência de senso de coletividade e sujeição de parte da população à violência pela elite: a

6 Confederação da Agricultura e Pecuária do Brasil, entidade organizadora da classe produtora rural e da agroindústria e representativa dos interesses da categoria junto à política agrícola nacional.

7 Confederação Nacional dos Trabalhadores na Agricultura, entidade sindical dos trabalhadores rurais da agricultura e do extrativismo, permanentes ou temporários, assentados ou não, e das atividades rurais familiares.

8 Em seu número 66, de I7 de fevereiro de 20I0, o Jornal da CONTAG publicou a manchete "PNDH-3 fortalece bandeiras do movimento sindical do campo", em que declarou o apoio da entidade à terceira edição do Programa, que "incorpora reivindicações históricas dos trabalhadores e trabalhadoras rurais". 
dizimação dos indígenas e a escravização dos africanos (Ginzburg, J. "Escritas da tortura", in: Safatle, V. \& Teles, E. (org.). O que resta da ditadura, p. 133). $\mathrm{Na}$ ditadura militar, uma parcela da classe média entra para o rol de camadas da população vítimas de sevícia. Mas a opinião pública tanto abandonou os perseguidos políticos quanto havia esquecido os índios e os negros, assim como renega hoje a classe baixa e negra que frequentemente é abusada pelo poder policial. Para Maria Rita Kehl, ninguém desconhece que houve e ainda há tortura no Brasil; no entanto, não se reconhece no povo a convicção de que a prática é intolerável. Assim, a tortura continuará sendo praticada enquanto nós não assumirmos a voz dos sujeitos calados por seus torturadores (Kehl, M. R. "Tortura e sintoma social", in: Ibid. pp. 128-3I). Frente à falta de identificação do brasileiro médio com seus compatriotas vítimas de tortura, como o PNDH-3 pode buscar adesão popular quanto à questão do direito à verdade e à memória sobre o período ditatorial?

Paulo Vannuchi - O tema do direito à memória e à verdade é muito mais importante do que o mero tratamento das questões do paradeiro dos restos mortais dos perseguidos políticos - datas, locais, condições de morte ou desaparecimento etc. O tema traz uma ideia que nós, da ciência política, chamamos de "nation building", que se trata da construção da nação como resultado de processos criativos, construtivos, marcos importantes. Um país constrói um mito sobre a sua própria história. O Brasil, segundo a Marilena Chauí, tem o "mito edênico" do descobrimento, a visão de Pero Vaz de Caminha, o que na verdade é a história de um genocídio indígena. Outros países colonizados, como os Estados Unidos, produziram obras-primas que discutem seu passado, como Enterrem meu coração na curva do rio e $O$ último dos moicanos, mas no Brasil isso não ocorreu. Mesmo a nossa literatura indianista, de Alencar, do I-Juca Pirama [de Gonçalves Dias], é sempre uma exaltação do indígena. Nunca foi discutido o conflito que reduziu os estimados cinco milhões de indígenas a $250 \mathrm{mil} \mathrm{em}$ I988 - hoje a população indígena voltou a ser de quase um milhão, por conta dos direitos constitucionalmente estabelecidos. Quanto à escravidão, há uma enorme dificuldade para se compreender o racismo. As cruzadas travadas pelo Ali Kamel ${ }^{9}$ e pelo Demétrio Magnoli ${ }^{10}$ decorrem do fato de que o país nunca tratou a sério a história da escravidão. Nós aprendemos na escola a sequência das

9 Sociólogo e jornalista, diretor da Central Globo de Jornalismo, é autor de Não somos racistas entre outros títulos.

IO Sociólogo, jornalista e doutor em Geografia Humana pela USP, é autor de Uma gota de sangue - história do pensamento racial entre outros títulos. 
leis da abolição: Bill Aberdeen, Lei do Ventre Livre, Lei dos Sexagenários, Lei Áurea. Bom, e o processo? Mais tarde, eu comecei a aprender com poemas de Castro Alves. Foram três séculos e meio e nós não sabemos datas nem números. Rui Barbosa é o responsável pela ordem de mandar queimar os arquivos que continham esses dados. Se não tivesse feito isso, o direito à memória e à verdade da escravidão poderia ter produzido peças de interpretação riquíssimas e com mais seriedade. Mas sabe-se que navios negreiros traziam metade da carga viva, sabese que a tortura era utilizada diariamente como instrumento de suplício. Isso marca profundamente a construção do Brasil. O Florestan Fernandes, no livro A integração do negro na sociedade de classes, e o próprio Fernando Henrique Cardoso, no seu Capitalismo e escravidão no Brasil meridional, mostram como a abolição da escravidão não foi acompanhada de nenhuma política. O século XX foi marcado por esse problema, tanto que até hoje o negro é mandado para o elevador de serviço, contrariando preceitos constitucionais. Se tivéssemos seriamente criado no sistema escolar o processamento da história, teria nascido de uma justa compreensão da escravidão um sentimento ético de reparação, de respeito, de sensibilidade com a questão da igualdade. E não são só o genocídio indígena e a escravidão: temos quatro séculos de latifúndio, coronelismo, enxada e voto ${ }^{\mathrm{II}}$. O latifundiário era Executivo, Legislativo e Judiciário, e era o padre também; dispunha da vida, matava, torturava, ferrava o adversário com ferro de gado, na linha do Sargento Getúlio ${ }^{12}$. Isso também se passa em episódios como Canudos, Contestado, Pedra Bonita e Caldeirão. Os grandes heróis militares do Brasil são figuras que percorreram o Império e depois a República, enfrentando Cabanagem, Balaiada, Farroupilha, Confederação do Equador, os surtos libertários que o Brasil teve. Em 2010, pela primeira vez o Brasil tem a possibilidade de fazer diferente. Lutemos para fazer diferente: não um revanchismo, mas um processamento. Segundo a Maria Rita Kehl, as nações são algo do que são os indivíduos: se a nação não processa o trauma, se não trabalha o conhecimento, se não promove o diálogo em torno dele em sala de aula, nós não conseguimos compreender a violência à nossa volta. É possível um mundo de paz e já temos o roteiro para ele, que são os trinta artigos da Declaração Universal dos Direitos Humanos. E é preciso, definitivamente, apostar na convivência humana. Não vamos discutir Canudos ou a escravidão, em virtude de toda a dificuldade

II Alusão ao clássico Coronelismo, enxada e voto, publicado em 1948, de autoria de Victor Nunes Leal, jurista brasileiro morto em 1985 .

I2 Alusão ao romance Sargento Getúlio de João Ubaldo Ribeiro, publicado em I97I, narrativa monológica de Getúlio Santos Bezerra, sargento da polícia militar e jagunço do líder local Acrísio Nunes, sobre a última incumbência que recebe antes de se aposentar: sequestrar um adversário político de seu chefe. 
documental, mas a nação é capaz de discutir a recente ditadura - hoje em dia até mais do que em I989, pois uma Comissão Nacional da Verdade naquela época seria tida como risco de retrocesso. Passaram-se décadas e agora quem está assumindo o debate é uma geração que não participou diretamente do trauma, que tem mais condições de analisá-lo com distanciamento.

Humanidades em Diálogo - O historiador francês Pierre Nora, em seu livro Les lieux de mémoire (Os lugares de memória), traça uma distinção fundamental entre a História, como ciência humana, e a memória coletiva. Diz ele que: "a memória está em permanente evolução, aberta à dialética da lembrança e do esquecimento, inconsciente de suas deformações sucessivas, vulnerável a todas as utilizações e manipulações, suscetível de repentinas revitalizações. (...) Sendo afetiva e mágica, a memória acomoda apenas os detalhes que lhe confortam. (...) Já a história é a reconstrução sempre problemática e incompleta daquilo que não é mais. (...) Por ser uma operação intelectual e laica, tem um apelo para a análise e para o discurso crítico". No seu artigo "Resgate da memória e da verdade: um direito de todos", o senhor retoma a concepção de verdade de Hannah Arendt como aquilo que "não se pode modificar" e ressalta a importância da "reconstituição da memória fundada na verdade". Tendo em vista o caráter maleável da memória e a sua significação política, que relação o senhor vê entre história, memória e verdade?

Paulo Vannuchi - Nós estamos adotando aqui a definição tradicional de verdade, porque a ONU a usa - não vamos inventar. A minha formação intelectual, filosófica e política passa por múltiplas fontes do humanismo e do socialismo. E atualmente passo muito por Bobbio e Hannah Arendt. Então, eu sei que a formulação da verdade não é fácil. Não podemos dizer: "a verdade está aqui na minha mão". O Renato Janine Ribeiro foi meu professor e ele é uma das pessoas que trabalham com isso. Bom, e o que é a verdade? Bobbio diz que a verdade é composta por diferentes olhares numa aproximação coletiva. O que nós estamos chamando de verdade não é o estabelecimento de um ponto de vista único sobre o regime de 1964 , porque isso seria autoritário, antidemocrático. As pessoas têm todo o direito de continuar pensando que o regime foi bom para o país, porque essas controvérsias são típicas da natureza da política - o medo que essas pessoas têm do comunismo, o convencimento que elas têm de que João Goulart era um terrível comunista às vésperas de fazer a revolução. $O$ que não pode é prevalecer discussão sobre se houve ou não houve tortura. Nós não queremos impor uma 
visão de que nós, da resistência, fomos os bons, e eles, do regime, foram os maus. Nós, intimamente, achamos que foi bom ter sido feita a resistência - ainda que aqueles que recorreram à luta armada tenham sido exterminados militarmente e que mesmo os que não lutaram tenham sido derrotados do ponto de vista imediato - e nos consideramos vencedores no processo histórico por estarmos agora nos apresentando para um diálogo desarmado - ainda que o outro lado não o aceite. $\mathrm{O}$ outro lado tem que distorcer o PHDH-3. Manchetes como "Contra a Lei de Anistia, PNDH-3 propõe Comissão da Verdade". Ora, era só ler o texto do PNDH-3. Mas o jornalista pode não se dar ao trabalho crítico de investigar que lei era aquela e engole uma visão de anistia errada, que não condiz com o que aconteceu. A Lei de Anistia que foi aprovada não foi aquela que levou os CBAs [Comitês Brasileiros de Anistia] às ruas. Foi um projeto aprovado por um regime bipartidário imposto, com leis todas carentes de sustentação constitucional - porque o país não tinha uma constituição ${ }^{13}$. Não adiantava um general dizer que havia constituição: juridicamente não havia. O nosso intuito é construir a democracia, construir o futuro. A verdade que propomos não tem nada de maniqueísta. Mas é verdade que o país passou por estes traumas e eles produzirão danos duradouros nas gerações seguintes, como os traumas da escravidão geraram. Em 2010 o Brasil já tem condições de discutir seus traumas - mas não é certo que vamos ganhar esta disputa. Ninguém acredita mais que a história tenha um porto, um destino inevitável: ela depende da ação humana, das classes em choque. O nosso esforço é o de propor essa discussão. E entendemos que o contraesforço não tem conseguido se manter nos trilhos de um debate democrático. Nossos detratores imediatamente falam em "revanchismo" e criam um espantalho que nenhum de nós sustenta - nem eu, nem a [então ministra chefe da Casa Givil] Dilma Rousseff, nem o [então ministro da Justiça] Tarso Genro. Para mim sequer importa se os acusados irão para a cadeia. A impunidade é que tem que ser rompida. E ela pode ser rompida com ou sem cadeia, com uma ação declaratória civil: "a Justiça Brasileira, em última instância, comprova que Carlos Alberto Brilhante Ustra, comandante do DOI-CODI, foi responsável pela morte de 46 pessoas e por 784 episódios de tortura relatados a esta comissão. Levando em conta a definição que o Supremo Tribunal Federal

I3 Não há consenso no meio jurídico sobre a legitimidade da Constituição de I969. No entanto, alguns constitucionalistas entendem que ela foi uma Emenda Constitucional à Constituição de I967, outorgada pelo governo militar $\left(E G n^{0} \mathrm{I}\right)$, visando à fixação do mandato presidencial em cinco anos, que teria entrado em vigor em 30 de outubro de I969, quando o general Emílio Garrastazu Médici assumiu a presidência. Esta Emenda seria considerada uma Constituição por si só pelo caráter outorgado que teve, além de ter modificado substancialmente um aspecto importante da Constituição anterior. 
$\operatorname{adotou}^{\mathrm{I4}}$, não pode ser sujeito a processo penal, mas que fique registrado que...”. Isso quebra a impunidade - os vizinhos vão saber, a filha vai perguntar. $O$ caso do Ustra é notório demais para tanto, mas muitos torturadores apresentam suas histórias a partir da pressão de familiares. Recentemente, um general francês, pressionado pelos bisnetos, escreveu um livro contando pela primeira vez a truculência cometida durante a guerra da Argélia - denunciada em muitos livros, como no clássico A tortura, de Henri Alleg, com prefácio do Sartre. O nosso esforço aponta para o convencimento. Às vezes temos atrito com familiares de vítimas que exigem que obriguemos os torturadores a falar. Mas como podemos obrigá-los sem torturá-los? Ora, estamos numa democracia, há direitos humanos. O que nós podemos fazer é convocá-los judicialmente, mas eles falam se quiserem, eles têm o direito constitucional de não responder às perguntas. É preciso apostar no caminho do convencimento. Então, como só resta à reação inventar um inimigo, eles inventam o revanchista. Eu não tenho dúvida de que é preciso assumir, sem nenhum receio, um ideal de reconciliação - do que antigos companheiros meus já não gostam. O nosso intuito é qualificar a reconciliação, o que significa exigir saber tudo, abrir todos os arquivos. Com a Comissão da Verdade, teremos a oportunidade de ouvir milhares de pessoas - que, eu espero, apareçam para contar em todos os detalhes como tudo aconteceu - e faremos um relatório final, que deverá ser transformado em instrumento de formação escolar. A partir do conhecimento de tudo que aconteceu, todas as concepções políticas, sem maniqueísmo, vão aprender para não repetir. Evidentemente o conhecimento dos arquivos será um aprendizado para o setor conservador, que está revelando em seu ataque ao $\mathrm{PNDH}-3$ um arraigado vínculo com aquele modo de pensar que produziu a ditadura militar, mas também os herdeiros do bloco insurgente terão que pensá-lo, porque eles muitas vezes não revelam clareza sobre o que aconteceu no passado do país. Nós, os resistentes, não éramos anjos, nós também erramos naquele período e podemos errar hoje. A democracia é essa convivência. Então, vamos transformar os traumas em diálogo.

I4 No dia 30 de abril de 20I0, o Supremo Tribunal Federal rejeitou, por sete votos a dois, a proposta de revisão da Lei da Anistia feita pela Ordem dos Advogados do Brasil. O relator da ação da OAB, o ministro Eros Grau - que, mesmo tendo feito parte da resistência à ditadura, votou contra a revisão da lei - argumentou que não cabe ao STF alterar um texto normativo produzido por um amplo debate entre intelectuais, políticos e entidades de classe, entre as quais a própria $\mathrm{OAB}$. O debate concluiu que a anistia brasileira é válida e que, portanto, não deve haver processamento tampouco punição aos agentes do Estado que praticaram crimes de lesa-humanidade contra opositores do regime, pois, tendo sido a anistia ampla, geral e irrestrita, tanto estes quanto aqueles foram anistiados. Todavia, entre todos os ministros foi unânime a reprovação da prática da tortura e a convicção de que é preciso que a sociedade tenha acesso aos arquivos da ditadura. Os dois votos favoráveis à revisão foram os dos ministros Ricardo Lewandowski e Carlos Ayres Britto. 
Humanidades em Diálogo - O Poder Executivo, por seu caráter representativo e pela atual sustentação política em uma ampla base aliada, enfrenta dificuldades notórias no encaminhamento e na solução de questões polêmicas, como a dos direitos humanos. Essa tensão percorre a reformulação do PNDH3 no que se refere aos temas do aborto, da união civil e da adoção pelos casais homoafetivos, das ocupações de terra e do direito à memória e à verdade. O Judiciário, por sua vez, é um poder contramajoritário, que justifica suas decisões e fundamenta sua legitimidade não apoiado em regras de maioria, mas nas supostas imparcialidade e natureza eminentemente técnica de suas atribuições. Diante disso, como o senhor analisa a possibilidade de êxito das tentativas de obter a concretização dos direitos humanos via Poder Judiciário, contornando os obstáculos colocados à discussão desses temas a partir do Executivo?

Paulo Vannuchi - A construção dos direitos humanos é sempre referenciada à proteção dos cidadãos perante o Estado. Nós temos hoje no Brasil talvez algo do "Estado ampliado" do Gramsci, marxista que não via mais o Estado como "comitê executivo da classe dominante", expressão que aparece no Manifesto do Partido Comunista do Marx. Evoluindo a visão marxista de Estado, Gramsci pensa um Estado que se abre à disputa de classes em seu interior. E, como condição para a realização deste "Estado ampliado", temos um Estado em que Lula é presidente, um homem que vem de um partido como o PT, de pensamento socialista. Nesse sentido, chegamos a ter no Brasil essa raridade que é um Ministério de Direitos Humanos - que causa muita estranheza nas nossas viagens. As pessoas não sabem o que o Ministério faz. Tradicionalmente, a defesa dos direitos humanos é uma ouvidoria, uma procuradoria, um órgão fora da sociedade civil. Historicamente, a construção dos direitos humanos se deu a partir da sociedade civil. Antes de I964, mal se falava em direitos humanos. Mesmo partidos de esquerda não abordavam. $\mathrm{Na}$ luta contra a ditadura, as violações dos direitos humanos contra os opositores apareciam como tema, mas não aparecia o combate à tortura de presos comuns. Com seis anos de idade, eu me lembro de ouvir gritos, na minha pequena São Joaquim da Barra, vindos da delegacia, que devia ter uma cela só, quase em frente à minha casa; eu perguntava para a minha mãe o que era aquilo e a minha mãe, um pouco chateada, mas com a maior naturalidade, me falava: "aí tem preso e preso apanha”. Senso comum: preso apanha para confessar, para entregar o produto do roubo. Então, no Brasil, a Igreja Católica não levanta uma "pastoral da tortura contra preso comum", ela levanta a defesa do opositor político. Quando o regime começa a acabar, a sociedade civil articula o MNDH, Movimento Nacional dos 
Direitos Humanos - que já está com quase 30 anos de vida. As universidades começam a ter pequenos núcleos e começam a fazer pressão. O primeiro poder sensível foi o Legislativo: primeiro, no Rio Grande do Sul, a Comissão de Direitos Humanos da Assembleia Legislativa; depois, a Comissão da Câmara Federal dos Deputados; e, só recentemente, o Senado cria a sua comissão. E a pressão começa a chegar ao Executivo: Franco Montoro, governador de São Paulo eleito em I982, em I983 já começa a aplicar políticas de direitos humanos; inclusão de curso de direitos humanos na Academia de Polícia. Quanto ao Judiciário, o poder normatizador por excelência, há a questão dos tratados internacionais. A construção dos direitos humanos sempre foi - e no Brasil fortemente é - a adesão aos tratados: em I948, a Declaração Universal dos Direitos Humanos; depois, a Convenção contra o Racismo, a que o Brasil adere em pleno regime ditatorial, como demanda da política africanista; logo em seguida, nos primeiros anos da transição, a Convenção contra a Tortura, a Declaração dos Direitos da Mulher, a Declaração dos Direitos da Criança e do Adolescente. Desde o final de 2005, no debate em torno da II ${ }^{\mathrm{a}}$ Conferência de Direitos Humanos, o esforço de reconstruir a relação, então muito tensa, entre os movimentos sociais e o governo exigiu não manter a agenda dos direitos humanos direcionada exclusivamente ao Poder Executivo. Era preciso contar com o Poder Executivo - no caso, com o Lula, pela figura que ele é -, mas também incorporar cada vez mais o Judiciário. Nesse sentido é que nós tentamos essa novidade que eram as recomendações ${ }^{\mathrm{I} 5}$. Pela palavra "recomendação" nós entendemos uma recomendação e eles entenderam uma imposição. Aliás, o julgamento do Supremo Tribunal Federal é uma prova eloquente de que nós tínhamos razão. E acho que temos que fazer uma aposta: o Executivo terá que ser sensível ao tema dos direitos humanos até por razões eleitorais. Ele passa por um teste a cada quatro anos e os temas dos direitos humanos, na forma de educação, saúde, moradia, comida, segurança alimentar e os demais, vão aparecer na pauta. O Judiciário, não: ele é o poder que não passa pelo voto popular. Então, nós temos a tarefa de trabalhar junto ao Judiciário e aos cursos de Direito, porque é preciso trabalhar a formação de juízes, que são quem vai representar a maior questão, que é novamente bobbiana: o problema dos direitos humanos não é mais a fundamentação, mas a efetivação. Nós temos os direitos da criança e do adolescente muito bem aplicados à rotina prática,

I5 Os Programas Nacionais de Direitos Humanos não podem obrigar os demais poderes a atuar, seja de que forma for, seja em que sentido for. Acontece que nas conferências, as sugestões e propostas não são técnicas e não identificam os limites de um programa. Por isso, a solução encontrada foi colocar as propostas que envolviam outros poderes sob a forma de "recomendações", que não têm qualquer tipo de exigibilidade legal ou extralegal. 
os direitos da mulher, o combate à tortura, o combate ao trabalho escravo. Nós estamos fazendo pressão pela PEG-438, a emenda constitucional sobre a expropriação de terra. O Código Penal brasileiro já é mais do que suficiente, as NRs [normas regulamentadoras] trabalhistas, para não haver trabalho escravo no Brasil. Nós fizemos a IO ${ }^{a}$ Oficina sobre Trabalho Escravo no Ceará, cada dia com cerca de 60 juízes trabalhistas e procuradores; foram seis horas de trabalho em que apresentamos o que é o trabalho escravo, as redes, as empresas, os procedimentos judiciais. E não é com hostilidade que eu reajo à questão da decisão do Supremo Tribunal Federal. É respeitando - como é preciso no meu papel. Valorizando os votos de Ricardo Lewandowski e Carlos Ayres Britto [ministros do STF]. E lamentando. Mas seria pior se a construção da justificativa da decisão fosse só pelo argumento - que eu confesso que sempre me incomodou muito - de que a tortura praticada em I970 não pode ser examinada pela imprescritibilidade prevista pela Constituição de I988. Por mais que a minha turma dos direitos humanos me despeje argumentos de que eu seja uma pessoa que tem lado, em política a gente tem que ter lado; e o meu lado é este, então eu argumento. Mas me incomoda o argumento de que a imprescritibilidade de I988 não vale para a tortura de I970. E ele é muito forte no Direito, tanto que o contra-argumento é amealhar uma dezena de outros instrumentos: Convenção de Genebra, Convenção de I9Io, Carta das Nações Unidas, Declaração Universal. Se a decisão tivesse sido justificada assim, eu lamentaria. Mas a construção do argumento sobre o que foi a Lei da Anistia só reforça a importância do resgate da memória, de propor um debate nas faculdades, nos trabalhos, na mídia. Discordemos pelo resto da vida sobre o que foi a escravidão no Brasil, mas nós não podemos falar que o Gilberto Freyre é um arrematado idiota. Ele é um dos intérpretes do Brasil: é dele a teoria da miscigenação, da democracia racial. Se ele pinta uma escravidão açucarada, apresentemos outra. E vamos conviver democraticamente com mais de um intérprete. Agora, não deixemos que o Gilberto Freyre diga que não havia pelourinho. Então, é nesse sentido que o Judiciário também tem uma importância muito grande.

Humanidades em Diálogo - Está em curso o primeiro julgamento internacional do Brasil por crimes de violação aos direitos humanos durante a ditadura civil-militar (I964-85). Nos dias 20 e 2 I de maio, ocorreram audiências públicas na Corte Interamericana de Direitos Humanos referentes ao caso Guerrilha do Araguaia, que compreende detenção arbitrária, tortura, execuções sumárias e desaparecimento forçado de pelo menos 70 pessoas durante operações das Forças Armadas brasileiras executadas entre I972 e 
$1975^{16}$. Considerando a jurisprudência já consolidada no âmbito do sistema interamericano de direitos humanos e uma vez que este tipo de crime é considerado imprescritível e impassível de anistia, em breve deverá o Estado brasileiro ser condenado a rever a posição recentemente externada pelo Supremo Tribunal Federal, que declarou estarem abrangidos pela Lei de Anistia também os crimes de violação aos direitos humanos praticados por agentes públicos durante o regime militar. Sendo vinculante a decisão da Corte, como o senhor pensa que ela impactará o governo brasileiro?

Paulo Vannuchi - Na última sexta-feira [dia 28 de maio de 20Io], na mesa de direitos humanos do evento da ONU Aliança das Nações, eu fiz a seguinte fala: "seguimentos brasileiros consideram que uma eventual condenação pela Corte da Costa Rica será uma quebra da soberania brasileira". Eu quis fazer esta fala, cautelosamente, para fazer um contraponto a uma inaceitável declaração do meu colega Nelson Jobim ${ }^{\text {I7 }}$. Primeiro, um ministro da defesa não pode fazer uma declaração que em tese só poderia ser feita pelo presidente da república, quem sabe pelo chanceler. Ministro da defesa não é presidente, não é chanceler. Ele tem uma área de atribuição importantíssima, como eu tenho a minha. Ele fez uma declaração que quebra um acúmulo - com certeza de I6 anos, de Fernando Henrique a Lula, mas possivelmente um pouco mais do que isso, talvez também Itamar Franco e Fernando Collor - de adesão do Brasil ao sistema [Organização dos Estados Americanos]. Ele está construindo uma nova visão. Foi uma primeira declaração um pouco à la Fujimori, ou à la Toledo, que fez uma dessas recentemente. Ou mesmo à la Chávez, que está num tremendo contencioso contra a OEA - Direitos Humanos, porque não está aceitando o relatório, feito pelo [relator especial para direitos humanos da ONU] Paulo Sérgio Pinheiro, segundo o qual na Venezuela as ONGs que são a favor do governo são apoiadas financeiramente e valorizadas, enquanto as que são contra são reprimidas e perseguidas. Coisa que uma comissão de direitos humanos tem que dizer. As pessoas, gostando ou não do Chávez, têm que discutir a questão dos direitos humanos em si, sem conotação ideológico-partidária. Eu não sei dizer

I6 É importante lembrarmos que essa pergunta foi feita em 20I0. Nesse mesmo ano, o Brasil foi condenado pela Corte Interamericada de Direitos Humanos.

I7 Às vésperas do julgamento do Estado brasileiro, acusado de detenção arbitrária, tortura e desaparecimento de membros do PCdoB que atuavam na Guerrilha do Araguaia e de camponeses que viviam na região, pela Corte Interamericana de Direitos Humanos na Costa Rica, o ministro da defesa Nelson Jobim teria dito que Brasília pode se negar a acatar uma decisão condenatória de parte da Corte - como se o Brasil, como país signatário da convenção que criou o tribunal, não tivesse obrigação de respeitar as suas decisões sobre os crimes cometidos durante a ditadura militar. 
qual será a reação. Primeiro, nós não sabemos qual será a decisão. Por analogia, a tendência muito maior é a de haver alguma forma de determinação ao Brasil para rever a Lei de Anistia, no sentido de que há um antecedente peruano e um chileno, cujas leis de anistia foram claramente consideradas autoanistias. Se elas são, a do Brasil é. Era vigente o regime militar seis anos antes de acabar o governo Figueiredo. Lembremos que o Alencar Furtado, líder do MDB, foi cassado dois anos antes da Lei de Anistia. Evidentemente, o MBD não era um partido livre, mas um partido em que a cada discurso de tribuna o sujeito tinha que medir se aquele discurso podia lhe valer uma cassação ou não. A história recente do Brasil é muito reconhecida pelo sistema ONU-OEA de Direitos Humanos. O Brasil, como um país que tem desigualdades estruturais muito superiores às do Chile, da Argentina e do Uruguai, é reconhecido por ser um país que não faz a negação dos problemas, que os reconhece, que os discute, que tem políticas. Por que agora fazer um contra-ataque com a questão da soberania nacional à la Fujimori? É inaceitável - para além do fato de um ministro da defesa não poder fazer uma declaração dessa natureza. É claro que, decidindo assim, vai haver um momento em que o Supremo Tribunal Federal terá que fazer outro debate, que será então sobre a hierarquia, que não é uma questão simples. Eu não sou jurista. Entendo que você dizer que a lei nacional não tem nenhuma importância é inaceitável, porque ela tem. A ONU não é o "governo mundial" do Kant ${ }^{\mathrm{I} 8}$. A ONU é um processo histórico, importantíssimo, duradouro, a grande chance que nós temos de caminhar para um mundo de paz. Um mundo sem ONU seria muito pior do que com a ONU, mesmo cheia de problemas, como os que ela tem hoje. Eu acredito que, com um debate mais sereno, o Brasil não vá tomar uma posição fujimoriana, truculenta, típica das Repúblicas de Banana. Eu reagi à decisão do Supremo Tribunal Federal do final de abril na linha de oferecer um caminho para que ele reforme a jurisprudência. E eu quero dizer que sempre discordei da oportunidade e da forma da $\mathrm{ADPF}^{\underline{19}}$ e falei com todos os autores na hora. Como eu tenho lado, fui defendê-lo e continuo defendendo. Por que achei uma estratégia equivocada? Porque era provocar o Supremo inteiramente a frio. Importantes juristas vieram me dizer que discordam da construção técnica; aquilo

I8 Alusão ao opúsculo $\dot{A}$ paz perpétua, de Immanuel Kant, publicado em I795, em que, segundo a interpretação de alguns juristas, o autor anuncia o advento da Organização das Nações Unidas.

I9 Arguição de Descumprimento de Preceito Fundamental é a ação interposta perante o Supremo Tribunal Federal para evitar ou reparar lesão a preceito fundamental resultante de ato do Poder Público. A ADPF $\mathrm{n}^{\mathrm{O}} \mathrm{I} 53$, interposta pelo Conselho Federal da OAB, tem por objetivo fazer com que a Lei de Anistia seja interpretada de forma a não abranger como crimes políticos os crimes de tortura, desaparecimento forçado e demais crimes comuns cometidos pelo Estado durante a ditadura militar. 
poderia ter sido feito na forma da questão dos tratados internacionais, e não na forma da recepção ou não recepção ${ }^{20}$. Porque o tema da recepção possibilita uma questão: em tese a Constituição formata a constitucionalidade a partir de sua vigência. Por que o Supremo foi provocado a frio? Porque, rigorosamente, não há uma questão judicial sobre o tema no Brasil. Quatro, seis, no máximo, ações judiciais. Na Argentina, no Ghile, no Uruguai, são centenas: aí o Supremo entende que há uma questão constitucional. E eu, há quatro anos e meio, estou clamando por ações judiciais. Evidentemente ficou um espaço enorme para o livre-arbítrio - no sentido neutro da palavra, não no de arbitrariedade-decidir. Eu lamento, em especial pelos vínculos de respeito, até pessoais, que eu sempre tive pelo [então ministro do STF] Eros Grau. E também não posso reagir dizendo que ele é um canalha; ele é um sujeito que por alguma razão tomou esta decisão. Nesse sentido, há novamente um efeito paradoxal. Se ali o Supremo tivesse decidido o oposto, seria mais difícil votar a lei no Legislativo, porque o Legislativo é o palco onde também vai haver discussão. E, como vários dos ministros nos seus votos esquizofrênicos dão seta para a esquerda e viram para a direita, eles terminam dizendo que sua decisão não quer dizer que não se deva conhecer o que aconteceu. Entre os três grandes jornais brasileiros, a Folha de $S$. Paulo é o mais contraditório quanto a esta questão; publica matérias, estimula o debate. $O$ Globo e $O$ Estado de $S$. Paulo, por editorial, se posicionam claramente contra esse nosso empenho; e, sintomaticamente, no dia seguinte à decisão do Supremo, os editoriais dos dois saudaram a decisão e terminaram falando da importância de abrir os arquivos. Eu entendo que a decisão do Supremo - e a nossa vida é muito cheia disso: uma derrota aqui abre uma porta ali - aumentou muito a facilidade de aprovação da lei no Legislativo. Eu imagino que se o PT for muito bem sucedido na disputa eleitoral - e bem a ponto de poder ganhar a eleição no primeiro turno -, eu mesmo pediria ao presidente Lula que ele usasse o seu prestígio para aprovar o projeto ainda neste ano. Seria muito melhor que fosse aprovado ainda no governo Lula, com a sua força política, do que no da Dilma, pelo fato dela ter sido torturada, o que sempre introduz um elemento pessoal que não é bom. A história dos direitos humanos não tem senso comum. Porque, no senso comum, se a namorada abandona o namorado e começa a namorar outro, fazendo com que o ex-namorado se sinta humilhado, os direitos humanos do ex-namoradinho em tese poderão ter sido feridos. Ora, direitos humanos, no

20 Uma lei editada anteriormente à Constituição Federal de I988 pode ou não ser recepcionada por ela, que é hierarquicamente superior e mais nova. E foi essa a estratégia da ADPF: argumentar que a Lei de Anistia não era recepcionada pela Constituição Federal de I988. 
Direito, não é isso. Nenhuma ação de Fernandinho Beira-Mar, embora ele seja um criminoso hediondo, é violação de direitos humanos; os temas dele são crimes, homicídios, torturas. Violação de direitos humanos é a do agente do Estado. Aos que acham que a comissão vai examinar só um lado: serão examinados, como consta no projeto de lei, os casos de tortura, morte, desaparecimento, locais etc. Aos que acham que a comissão é contra o regime: comissões da verdade não devem dar opinião sobre o regime nem sobre a resistência, elas descrevem o processo. O primeiro desafio da Comissão da Verdade é conquistar credibilidade. E, para conquistar credibilidade, evidentemente, ela tem que dizer que houve um atentado a bomba no Aeroporto dos Guararapes onde morreu um general, que houve na guerrilha do Lamarca um tenente morto a coronhadas. Por isso é que a Comissão é concebida como sendo composta por notáveis. Desmond Tutu, na África do Sul; Ernesto Sábato, na Argentina. Procuraremos os sete integrantes aqui no Brasil, se a lei for aprovada. Não é para que entre uma pessoa como eu, que participou da resistência, na comissão. Os integrantes serão pessoas com distanciamento, com respeitabilidade. Esta é uma chance muito real que o Brasil tem neste momento, e é muito bom que tenha.

Humanidades em Diálogo - Recentemente, em razão da decisão do Supremo Tribunal Federal pela não revisão da Lei de Anistia, intelectuais protestaram por meio de artigos em jornais de grande circulação. Maria Rita Kehl, em artigo publicado no jornal O Estado de S. Paulo, afirma: "a pesquisadora norteamericana Kathrin Sikking revelou que no Brasil, à diferença de outros países da América Latina, a polícia mata mais hoje, em plena democracia, do que no período militar. Mata porque pode matar. Mata porque nós continuamos a dizer tudo bem. Pouca gente se dá conta de que a tortura consentida, por baixo do pano, durante a ditadura militar, é a mesma a que assistimos hoje, passivos e horrorizados. Doença grave, doença crônica contra a qual a democracia só conseguiu imunizar os filhos da classe média e alta, nunca os filhos dos pobres". O aumento da tortura e das mortes, por parte do Estado, representado pela força policial, indica que há continuidade autoritária no Brasil?

Paulo Vannuchi - Existem estudos que merecem a minha maior torcida. Eu gostaria demais que eles fossem verdadeiros, mas eles me parecem bons demais para ser. Eu estive com esta pesquisadora de Minnesota, a Kathrin Sikking. O problema dessa história de que se mata mais hoje do que no regime militar é o seguinte: qual é a base empírica do regime militar? Quem é que fazia pesquisas 
sobre morte em delegacias? É um mito equivalente ao mito de que a juventude de I968 era boa e a de hoje não. Senso comum: não tem nenhuma fundamentação empírica. Seria preciso haver pesquisas sobre a juventude de I968 e não havia. Seria preciso haver pesquisas sobre uma juventude que já existia e que nós não sabíamos que existia, que era a negra, da periferia. Nós achávamos que a juventude era essa aqui da Maria Antônia ${ }^{21}$. Pode ser que a juventude atual seja tão ou até mais generosa e politizada do que aquela, só que está fazendo a sua disputa no funk, no rap, usando outras formas de fazer a sua luta que não no enfrentamento de uma ditadura ou numa organização partidária. Questiono profundamente este estudo, embora eu torça por ele. Para mim seria ótimo poder apostar na linha de que, quando o país faz o processamento histórico do que aconteceu, realizase um ciclo de menos mortes. Não vejo nenhuma fundamentação empírica para isso no caso brasileiro. Não havia pesquisa, o regime ditatorial não permitia fazer. Então, é possível que se torturasse naquela época tanto quanto hoje. E as pessoas só não ficavam sabendo por que não havia Defensoria Pública, não havia Ministério Público independente, não havia gente com coragem para denunciar. Quando conseguiam denunciar, eram casos de torturados políticos. Não havia série histórica, não havia boletim. Nós não temos uma única pesquisa nacional até hoje sobre vitimização. Eu trabalho há quatro anos e meio tentando fazer uma. É preciso ter três, quatro décadas de pesquisa nacional de vitimização para poder falar em série. Então, embora eu torça, ainda não considero que haja uma prova disso.

Humanidades em Diálogo - Retomando o pensamento já citado de Renato Janine Ribeiro, a formação do Brasil passa por dois traumas fundamentais: a exploração dos nativos e a escravidão dos negros pelos colonizadores e pela elite que se consolidou. Não é difícil de vislumbrar a mesma fórmula de sujeição de parcela da população à autoridade violenta na história recente do país. E percebe-se que em todos esses eventos o poder se revezou entre a autoridade católica, a fundiária, a militar e a empresarial; sendo que quando uma das castas detinha a ordem era sempre apoiada pelas demais. O PNDH-3 traz à discussão pública questões que desagradam a todos estes pilares de poder da história brasileira, como a legalização do aborto, a mediação de conflitos

2I Rua da região central da cidade de São Paulo onde fica o antigo prédio da Faculdade de Filosofia, Ciências e Letras da Universidade de São Paulo - hoje Centro Cultural MariAntonia - e onde fica o ainda atual prédio da Universidade Presbiteriana Mackenzie. Em outubro de I968, a rua se transformou em campo de batalha, com o registro de um morto e vários feridos, por causa do enfrentamento entre os estudantes da USP e os da Mackenzie, respectivamente de maioria esquerdista e direitista. 
fundiários, o direito à verdade sobre a ditadura e o ranking nacional de veículos de comunicação comprometidos com os direitos humanos. Tendo essa coincidência em mente, o senhor entende que o debate em torno dos direitos humanos teria sido inibido pelas alterações exigidas na redação do Programa pelos religiosos, pelos latifundiários, pelos militares e pelo empresariado?

Paulo Vannuchi - Em I5 de dezembro de 2008, eu fiz um discurso dizendo o seguinte: "presidente, estes dois mil delegados aqui presentes [na II ${ }^{\mathrm{a}}$ Conferência de Direitos Humanos] confiam que o senhor transformará em decreto presidencial, como Fernando Henrique Cardoso fez em I996 e 2002, o máximo possível do que for aprovado aqui”. Em nenhum momento houve discussão. Não saíram problemas, mas resoluções da II $^{\mathrm{a}}$ Conferência. As resoluções são o momento da voz democrática ou, numa paráfrase com a psicanálise, o momento do desejo. Depois, é o trabalho, que então nós começamos, com os participantes e com as suas lideranças. E chegamos a um bom acerto. Quando terminou a negociação com a sociedade civil, havia discordâncias, críticas, mas um tremendo respeito por nós e nosso por ela. Eu sei que daqui a pouco nós vamos ser sociedade civil. Numa boa democracia não há mais lados definitivos. Há alternância: você está no poder hoje, amanhã será outro. Dentro do governo, o meu conflito com o [então ministro da Defesa] Nelson Jobim ${ }^{22}$ foi muito menor do que este que explodiu na imprensa. A gente foi negociando junto, ouvindo os argumentos um do outro: quando veio à negociação da Comissão da Verdade, ele mandou três chefes e os três foram contrários; então ele disse que defenderia a Comissão e os três aceitaram, desde que o exame fosse feito dos dois lados - aí começa a nascer esse tema semântico da bilateralidade. E lançamos o Programa. A reação a ele não é, na minha conviç̧ão, o pensamento brasileiro sobre os direitos humanos. Foi um surto, com um enorme over. Evidentemente temos problemas graves com a

22 Um conflito se instaurou entre o Ministério da Defesa e a Secretaria de Direitos Humanos, uma vez que a classe militar, representada pelo ministro Nelson Jobim, exigiu uma alteração na redação do decreto presidencial que prevê a criação da Comissão Nacional da Verdade, proposta pela II ${ }^{a}$ Conferência de Direitos Humanos. No texto lia-se que a comissão teria a incumbência de "promover a apuração e o esclarecimento público das violações de direitos humanos praticadas no contexto da repressão política ocorrida no Brasil durante o período fixado pelo art. $8^{\circ}$ do Ato das Disposições Constitucionais Transitórias". Não obstante a redação fosse fiel ao relatório da Conferência endossado pela sociedade civil e assinado por 3I Ministérios, Jobim argumentou que seria preciso substituir a expressão "repressão" por "conflito" para que a investigação abarcasse os crimes cometidos tanto pelos militares quanto pelos militantes de esquerda. A solução encontrada pelo presidente Lula para sanar o conflito entre as pastas e garantir a bilateralidade da investigação foi baixar um novo decreto, no qual se lê que a comissão irá "examinar as violações de direitos humanos praticadas no Brasil durante o período fixado pelo art. $8^{\circ}$ do Ato das Disposições Constitucionais Transitórias". 
questão dos direitos humanos, senão não haveria um surto como esse. Mas não vamos achar que é esse o ponto. O documento está bem costurado: ele introduz em seis eixos uma temática circular, sendo que cada eixo se conecta com os outros. I ${ }^{O}$ Tema: Democracia. Se não houver democracia, com cobrança e governos abertos a isso, o resto vai se comprometer. $2^{\mathrm{O}}$ Tema: Desenvolvimento. $\mathrm{O}$ dedo na ferida: se é para discutir projetos de desenvolvimento, tem que discutir ribeirinho, quilombola, pescador, quebradeira de coco etc. $3^{\mathrm{O}}$ Tema: Universalização de Direitos. É a temática dos seguimentos: os direitos da criança e do adolescente, o direito à diversidade sexual etc. $4^{\mathrm{O}}$ Tema: Segurança Pública. Um grande capítulo novo para desbloquear o contencioso entre polícia e direitos humanos: policial não pode torturar, matar, executar - pode matar só naquelas condições muito estritas. $5^{\circ}$ Tema: Educação e Direitos Humanos. O capítulo mais estratégico de todos. $6^{\circ}$ Tema: Direito à Memória e à Verdade. O capítulo mais curto, negociado, moderado. Quem depois me transformou em herói já estava me chamando de traidor quando veio a pancadaria toda. Foram 52I ações. As nove alterações feitas não ferem a consistência do Programa. Houve eliminação de dois temas: o tema do ranking e o tema dos símbolos religiosos. Sobre a questão dos símbolos religiosos ${ }^{23}$, um importantíssimo militante de direitos humanos, secretário estadual da justiça do Mário Covas, advogado de preso político e membro da Comissão Especial de Mortos e Desaparecidos, o Belisário dos Santos Júnior - que já quis sair da comissão várias vezes, mas eu imploro para ele ficar, porque eu preciso de uma pessoa como ele, do PSDB, para mostrar que a Comissão não é de governo, mas de Estado - veio com um parecer de que o crucifixo é muito mais uma questão da formação histórica nacional, comparável à presença do Pantheon na Grécia, do que um ataque ao laicismo do Estado - como em vários países islâmicos a pessoa é condenada no Judiciário com base em preceitos do Corão. Além disso, não era uma questão que movimentasse um seguimento, como é o caso do aborto e do movimento feminista. Sobre a questão da mídia, $O$ Estado de S. Paulo, Folha de S. Paulo e $O$ Globo têm uma enorme dificuldade para lidar com o tema do regime - que eles propagandearam. Eles foram aos quartéis pedir para que os militares viessem. Apoiaram o regime até o momento em que tamanha foi a repressão que os jornais começaram a debandar. No caso do Globo, não: era um pequeno jornal local do Rio de Janeiro que o regime transforma então na grande rede. A Folha cedeu viaturas para emboscadas do DOI-CODI [Destacamento de Operações de Informações - Centro de Operações

23 No bloco estratégico de respeito às diferentes crenças, liberdade de culto e garantia da laicidade do Estado, previsto pelo PNDH-3, foi revogada a ação programática: "desenvolver mecanismos para impedir a ostentação de símbolos religiosos em estabelecimentos públicos da União". 
de Defesa Interna]. O Estado representa o pensamento cafeicultor de I932, da UDN. Então, eles têm uma enorme dificuldade para lidar com isso. Saúdo novamente a Folha que, como linha editorial, neste momento é o jornal que tem mais abertura para isso - embora bons jornalistas emplaquem boas matérias no Globo e no Estado. E a questão do latifúndio é com a Kátia Abreu. Não é o agronegócio brasileiro, é um seguimento da UDR [União Democrática Ruralista] que neste momento coordena a organização nacional [Confederação Nacional da Agricultura e Pecuária do Brasil]. E a Igreja, entre esses quatro setores, é o único que tem uma história recente de importância na defesa dos direitos humanos. Ela mudou muito: o Vaticano quebrou a coluna da Teologia da Libertação ${ }^{24}$; não é mais a Igreja de Dom Paulo Evaristo Arns ${ }^{25}$, Dom Hélder Câmara ${ }^{26}$ e Dom Pedro Casaldáliga $^{27}$. Ela já disse que não se dá por satisfeita, porque o tema do aborto ${ }^{28}$ foi mantido. E foi mantido de uma maneira tal que, quando o movimento das mulheres quiser incorporar aos seus futuros manifestos os posicionamentos do governo brasileiro sobre a questão do aborto, terá a frase, que ainda é a mais avançada de todas, que permaneceu na redação do $\mathrm{PNDH}-3$. O presidente Lula expressou a sua discordância sobre este ponto - o único reparo que ele fez para mim até hoje sobre o texto inteiro -, dizendo que não concorda com a frase sobre a autonomia da mulher para decidir sobre o seu próprio corpo. Eu fui então

24 Corrente político-religiosa, influenciada pela cultura católica francesa progressista, que surge no Brasil no início da década de 60 - estendendo-se à América Latina nos anos 70 -, com a proposta de transformação social em nome do cristianismo, privilegiando a crítica ao dogmatismo. Baseada na acusação moral do capitalismo como sistema injusto e no uso de instrumentos marxistas para a compreensão das causas da distribuição desigual de riquezas, a corrente é uma alternativa à doutrina cristã tradicional na medida em que seus fundamentos contrariam o preceito caritativo cristão: em vez de ser alvo de compaixão, os desfavorecidos devem ser os protagonistas de sua emancipação social.

25 Arcebispo emérito de São Paulo e doutor em Letras pela Sorbonne, é sobretudo conhecido por sua atuação política durante a ditadura, criando a Comissão Arquidiocesana de Direitos Humanos, intercedendo pelas famílias dos presos e desaparecidos políticos junto às autoridades militares e solidarizando-se com os movimentos sindicais do ABC.

26 Arcebispo emérito de Olinda e Recife morto em I999, durante a ditadura foi grande defensor dos direitos humanos, denunciando no exterior violações cometidas pelo Estado brasileiro quando o regime o impediu de acessar os veículos nacionais; foi o único brasileiro a ser - quatro vezes - indicado ao Prêmio Nobel da Paz e recentemente foi pedida a sua beatificação ao Vaticano.

27 De nacionalidade espanhola e brasileira, é bispo emérito de São Félix do Araguaia no Mato Grosso e também poeta; denunciou a existência de trabalho escravo e casos de tortura na Amazônia, foi defensor dos povos indígenas e solidário a vários focos de resistência política na América Latina, tendo sido diversas vezes ameaçado de expulsão do país no regime militar.

28 No bloco estratégico de garantia dos direitos das mulheres para o estabelecimento das condições necessárias para sua plena cidadania, previsto pelo $\mathrm{PNDH}-3$, lia-se: "apoiar a aprovação do projeto de lei que descriminaliza o aborto, considerando a autonomia das mulheres para decidir sobre seus próprios corpos"; mas esta ação programática foi alterada para: "considerar o aborto como tema de saúde pública, com a garantia do acesso aos serviços de saúde”. 
estudar as resoluções das I e II Conferências Nacionais de Políticas para Mulheres e constatei que a formulação das duas era muito anterior a esse ponto de vista feminista. Ora, a Conferência de Direitos Humanos aborda 47 temas. Não é bom que o aborto apareça com a formulação mais radical na Conferência de Direitos Humanos, sendo que não apareceu assim nas duas conferências que eram o fórum adequado para fazer esse avanço. Quando houve a decisão de manter a formulação que considera o aborto como questão de saúde pública, a Igreja não aceitou, assim como ela já não aceita o aborto nas condições em que a lei brasileira permite: estupro e risco de vida para a mãe - e o Supremo Tribunal Federal está examinando o caso da anencefalia ${ }^{29}$. Que discorde, como discorda do divórcio. E oriente os seus seguidores, os fiéis, a não praticarem. Senão há uma quebra da ideia de Estado laico, quando razões de fé viram vontade política. Eu declarei e repito: por mim não alteraríamos nada da redação. Agora, o Programa não é meu. Os outros dois eram Programas de Direitos Humanos, os que o Fernando Henrique assinou. Este Programa é de 3I ministros, o que o presidente Lula assinou. Então eu repito: recuo faz parte do dia-a-dia - não apenas da vida política, mas da nossa vida pessoal. Sobre questão do ranking ${ }^{30}$, foram mantidas ações que são mais graves do que esta, como aquela que suspendia a publicidade de veículos que divulgassem matérias com danos aos direitos humanos ${ }^{3 \mathrm{I}}$, que era a mais dura de todas - só que o empresariado não abriu a boca sobre este ponto para não passar recibo de que está preocupado com a receita das empresas e preferiu brigar por causa dos outros. O ranking, no fundo, era uma ideia positiva, era a ideia de prêmio, como o Prêmio da ANDI [Agência de Notícias dos Direitos da Infância] ou o Prêmio Vladimir Herzog de Anistia e Direitos Humanos. Agora, o ranking foi desqualificado. Então nós discutimos com o presidente e com o [então ministro das Comunicações Sociais] Franklin Martins, durante muito tempo, até

29 Em I2 de abril de 20I2, o STF dicidiu que aborto no caso de anencefalia não é crime.

30 No bloco estratégico de respeito aos direitos humanos nos meios de comunicação e o cumprimento de seu papel na promoção da cultura em direitos humanos, previsto pelo $\mathrm{PNDH}-3$, foi revogada a ação programática: "elaborar critérios de acompanhamento editorial a fim de criar um ranking nacional de veículos de comunicação comprometidos com os princípios de direitos humanos, assim como os que cometem violações".

3I Neste mesmo bloco estratégico, lia-se: "propor a criação de marco legal regulamentando o art. 22I da Constituição, estabelecendo o respeito aos direitos humanos nos serviços de radiodifusão concedidos, permitidos ou autorizados, como condição para sua outorga e renovação, prevendo penalidades administrativas como advertência, multa, suspensão da programação e cassação, de acordo com as gravidades das violações praticadas"; mas esta ação programática foi alterada para: "propor a criação de marco legal, nos termos do art. 22I da Constituição, estabelecendo o respeito aos direitos humanos nos serviços de radiodifusão concedidos, permitidos ou autorizados". 
a ideia de não mexer em nada sobre a imprensa. O presidente abriu o Programa e ficou lendo os textos de 2002, que são muito mais duros: há controle democrático e social sobre a imprensa, conceitos que não estão no PNDH-3. Nesse sentido, o terceiro é mais brando. Quando foram lançados os outros dois PNDH, não houve nenhuma chiadeira, porque rigorosamente o governo era dos empresários da imprensa; agora eles são oposição ao governo, eles são militantes. Então, depois de uma discussão em que o próprio presidente e o Franklin acharam melhor não mexer em nada, decidimos eliminar o ranking; mantivemos a ideia, mas não mais como regulamentação - o que juridicamente estava errado, trata-se de um artigo da Constituição não regulamentável -, e na sua efetivação valorizamos a questão do respeito aos direitos humanos como critério. Foi cortada a frase sobre a ameaça de cassação de concessão, para deixar mais uma vez reiterado que nós não somos chavistas, bolivarianos, castristas - pessoas que estão preparando o dia de criar uma grande e única TV pública brasileira e proibir a Rede Globo. Sobre os conflitos do campo ${ }^{32}$, nós tiramos a frase sobre a mediação como primeiro ato das demandas de conflitos agrários, porque, de fato, juristas rigorosamente considerados do campo dos direitos humanos ponderaram que aquela frase sempre suscita no Judiciário o argumento de que há intenção de limitar a autoridade dos magistrados. Como é muito importante a aproximação entre direitos humanos e Poder Judiciário, o próprio ministro [do Desenvolvimento Agrário] Guilherme Cassel e o seu ouvidor agrário nacional, o desembargador Gercino da Silva Filho, sugeriram que fosse excluída a questão do primeiro ato e fosse mantida a proposta de mediação pacífica de conflito. O que importa é o seguinte: em ocupação de terra não pode morrer gente. $\mathrm{O}$ ataque da Kátia Abreu é dizer: "ocupou terra, é bandido". Ela está convencida disso e ela representa o setor que pensa assim. E lamentavelmente a imprensa não tem tratado esta liderança como deveria. É uma liderança comparável a Jair Bolsonaro ${ }^{33}$. Vamos

32 No bloco estratégico de acesso à justiça no campo e na cidade, previsto pelo PNDH-3, lia-se: "propor projeto de lei para institucionalizar a utilização da mediação como ato inicial das demandas de conflitos agrários e urbanos, priorizando a realização de audiência coletiva com os envolvidos, com a presença do Ministério Público, do poder público local, órgãos públicos especializados e Polícia Militar, como medida preliminar à avaliação da concessão de medidas liminares, sem prejuízo de outros meios institucionais para solução de conflitos"; mas essa ação programática foi alterada para: "propor projeto de lei para institucionalizar a utilização da mediação nas demandas de conflitos coletivos agrários e urbanos, priorizando a oitiva do INGRA, institutos de terras estaduais, Ministério Público e outros órgãos públicos especializados, sem prejuízo de outros meios institucionais para solução de conflitos".

33 Capitão do Exército Brasileiro, foi eleito vereador do Rio de Janeiro pelo PDC e atualmente, filiado ao PP, exerce o seu sexto mandato consecutivo como deputado federal pelo Rio de Janeiro, tendo sido também filiado ao PPB, PTB e PFL; representante das Forças Armadas Brasileiras na Câmara Federal dos Deputados, é o único parlamentar brasileiro a defender abertamente o regime militar. 
tratá-la como especificidade de um sistema de representação que sempre permitirá alguém que tenha uma linha de conduta mais próxima do pensamento fascista uma democracia comporta isso -, e não como foi tratada, como se fosse uma liderança equilibrada. Muitas das ocupações de terra são feitas por pessoas que veem nisso o ato desesperado de manter a sua vida e a do seu neném. Na Constituição estão juntas "propriedade" e "função social": então vamos discutir isso assim. Os juízes vão continuar decidindo a favor da propriedade e ninguém está questionando isso. $\mathrm{O}$ PNDH-3 não questiona em nenhum momento o direito à propriedade privada. O que nós estamos dizendo é que uma reintegração de posse não precisa produzir Eldorado dos Carajás ${ }^{34}$ ou Corumbiara ${ }^{35}$.

34 No dia I7 de abril de I996, perto de uma povoação chamada Eldorado dos Carajás localizada no Pará, I55 policiais metralharam camponeses que bloqueavam a estrada em protesto pelo atraso - de cerca de 50 anos - dos procedimentos legais de expropriação de terra, matando I9 e ferindo dezenas de pessoas; três meses depois, a polícia paraense declarou inocentes os soldados envolvidos no atentado, que teriam agido em legítima defesa, e reclamou processamento judicial contra três dos camponeses, por desacato e posse ilegal de armas - os manifestantes estavam munidos de três pistolas, pedras e instrumentos de lavoura.

35 Na madrugada do dia 9 de agosto de 1995, em Corumbiara, no estado de Rondônia, 600 famílias sem-terra, acampadas na Fazenda Santa Elina, foram cercadas por policiais, mas, armadas de espingardas, resistiram à emboscada; ao amanhecer, acompanhada de assassinos profissionais - comprados ao preço de um latifúndio local -, a polícia invadiu o acampamento, o que resultou na morte de dez camponeses - entre os quais uma menina de sete anos atingida pelas costas - e dois soldados. 